\title{
PENGEMBANGAN PEMBELAJARAN BERBASIS WEBSITE DALAM MATAKULIAH PENGATURAN MESIN LISTRIK
}

\author{
Hamonangan Tambunan \\ FT Universitas Negeri Medan \\ email: hamonangantambunan@yahoo.com
}

\begin{abstract}
Abstrak: Penelitian ini bertujuan untuk mengembangkan sistem e-learning dalam bentuk pembelajaran berbasis website. Penelitian ini adalah penelitian dan pengembangan, yang melibatkan mahasiswa, guru SMK, dan dosen. Tahapan-tahapan dalam penelitian ini adalah: (1) analysis; (2) desain; (3) pengembangan; (4) implemementasi; dan (5) evaluasi. Data, yang dianalisis secara deskriptif, dikumpulkan melalui studi literature, reviu ahli, pengamatan, wawancara, angket, dan dokumentasi. Analisis menunjukkan bahwa kebutuhan dasar kegiatan pembelajaran dalam mata kuliah pengaturan mesin listrik, adalah: (1) pengelolaan bahan pembelajaran; (2) proses pembelajaran; (3) penyajian materi; (4) dapat diunduh oleh siswa; (5) proses pembelajaran inkuiri; (6) proses evaluasi; dan (7) bahan tersebut dibuat dalam bentuk animasi.
\end{abstract}

Kata Kunci: pembelajaran berbasis website, pengaturan mesin listrik

\section{DEVELOPING THE WEBSITE-BASED LEARNING FOR THE ELECTRICAL MACHINE REGULATION COURSE}

\begin{abstract}
This study was aimed at developing an e-learning system in the form of website-based learning. This was a research and development study, involving students, vocational high school teachers, and lecturers. The study stages were: (1) analysis; (2) design; (3) development; (4) implementation; and (5) evaluation. The data, analyzed descriptively, were collected through literature study, expert review, observation, interview, questionnaires, and documentation. The analysis showed the basic needs of learning activities in electric machine regulations, namely (1) the management of learning materials; (2) the learning process; (3) the presentation of the material; (4) downloadability by students; (5) inquiry learning process; (6) evaluation process; and (7) the material is made in the form of animation.
\end{abstract}

Keywords: web-based learning in electric machine regulation

\section{PENDAHULUAN}

Borang dan Akreditasi Jurusan Pendidikan Teknik Elektro (JPTE) FakulatasTeknik UNIMED tahun 2011menunjukkan IPK ratarata mahasiswa lulusan lima tahun terakhir adalah 2,95. Mahasiswa dengan IPK diatas 3,5 hanya $1,61 \%$. Demikian juga bila dicermati dari waktu yang dibutuhkan untuk lulus relatif lama. Keadaanini cenderung tidak berubah secara signifikan setiap tahun. Ini mengindikasikan ada masalah yang dihadapi mahasiswa dalam proses perkuliahan.

Hasil survei menggambarkan IPK yang diperoleh tersebut belum dapat mencerminkan kompetensi keahlian yang dimiliki.Lulusan ma- sih kurang dalamhal keterampilan mengajar dan penguasaan materi ajar khususnya pada bidang keahlian. Didapatkan data yang menjadi guru sebanyak $62,32 \%$ harus belajar kembali agar dapat mengajar di kelas dengan baik. Alumni yang bekerja pada sektor indutri hanya $2,30 \%$. Ini menggambarkan kompetensi bidang keteknikan lulusan masih rendah. Kelemahan ini dapat diakibatkan oleh proses perkuliahan yang belum berkualitas.

JPTE telah berupaya meningkatkan kualitas lulusan antara lain melalui (1) perbaikan kurikulum; (2) membentuk komunitas belajar; (3) peningkatan kemampuan dosen dalam pembelajaran; (4) perbaikan sistem evaluasi; serta 
(5) memberdayakan wadah Kelompok Dosen Bidang Keahlian (KDBK). Namun 39\% dosen masih menggunakan metode ceramah, dan sebagian besar perkulihan berpusat pada dosen. Kurikulum Berbasis Kompetensi (KBK) telah diimplementasikan di JPTE sejak tahun pelajaran 2005/2006 dengan menetapkan standar kompetensi lulusan dan standar proses dan evaluasi. Tetapi pembelajaran pada umumnya masih berorientasi pada penguasaan materi.

Berkaitan dengan hal ini perlu dirancang pendekatan pembelajaran yang dapat memadukan antara proses perolehan informasi baik bersifat eksplorasi dasar, pendalaman, pengayaan dan perluasan dipadukan dengan tatap muka dan website. Pendekatan yang selaras dengan harapan tersebut adalah e-learning berbasis websitedengan rancangan khusus. Asumsi dasar untuk ini adalah (1) mudah dan cepat digunakan; (2) kekuatan interkoneksi eksplorasi, pendalaman dan perluasan materi dari berbagai sumber; (3) mendorong ekspresi otonomi pembelajar; (4) mendorong terciptanya budaya belajar.

Tujuan tahap pertama penelitian ini adalah (1) membuat analisis kebutuhan terhadap pembelajaran berbasis website; (2) membuat analisis teknologi akan draft perancangan website; (3) merumuskan tugas analisis terhadap materi ajar.Selanjutnya digunakan sebagai(1) bahan masukan tentang penilaian kebutuhan akan website, (2) dasar dan acuan dalam merancang pembelajaran; (3) bahan masukan untuk kepentingan akan sumber belajar dalam bentuk website. Pembelajaran berbasis website merupakan bagian dari suatu e-learningyang dimanfaatkan (1) mengirim bahan ajar; (2) pendukung; (3) meningkatkan kualitas pembelajaran; dan (4) pembelajaran dan penilaian serta mendistribusikan materi pembelajaran sehingga dapat diakses di mana saja dan kapan saja serta siapa saja(Gilbert \& Jones, 2001; Rosenberg, 2001). Unsur-unsur yang harus dipenuhi dalam pembelajaran ini adalah (1) menggunakan teknologi web; (2) mengajarkan konten sesuai tujuan pembelajaran; (3) rancangan berdasarkan strategi pembelajaran dan prosedur pedagogis; (d) berisi elemen yang dapat digunakan kembali.

Berkaitan dengan hal di atas fitur-fitur yang diperlukan pada layanan web, yaitu (1) informasi pelajaran, catatan pengumuman dan jadwal; (2) peta kurikulum; (3) bahan ajar seperti slide, handout, animasi, audio video; (4) komunikasi melalui email dan forum; (5) penilaian formatif dan sumatif; (6) alat manajemen siswa (records, statistics, student tracking); (7). Link ke website terkait secara internal maupun eksternal yang bermanfaat seperti perpustakaan, online database, dan jurnal (Stone, 2002).

PBW dari sudut pandang teknologi menggunakan teknologi web dan layanan internet sebagai modus pengiriman. HTML, URL, browser, e-mail, dan fasilitas transfer file (FTP) digabungkan dengan unsur-unsur multimedia, seperti animasi, video klip dan audio, gambar, grafik, selain bahasa scripting, seperti PHP dan Java Script. Pengembangannya menggunakan perangkat lunak multimedia authoring, seperti Authorware, Macromedia Flash, Java, dan Hot Potatoes. Dari sudut pandang pedagogis multimedia merupakan strategi pembelajaran yang terkait dengan konstruktivis, kognitivis, dan paradigma pembelajaran kolaboratif atau kombinasi dari benerapa strategi (Conrad dan Voris, 2002). Dari sudut pandang isi yaitu implementasi berbasis komputer dari suatu subjek tertentu yang biasanya sesuai dengan kurikulum. Dengan demikian, PBW adalah integrasi dari (1) konten; (2) teknologi; dan (3) pedagogi menjadi suatu kesatuan sistem yang utuh mendukung pembelajaran.

Atas dasar hal tersebut penggunaan teknologi web dapat memperkaya pengalaman belajar dengan dimensi baru, yaitu (1) multimediality; belajar lebih mudah karena membantu mahasiswa untuk focus dan menjaga perhatian mereka pada isi yang kompleks, berkataktivasi indera yang berbeda; (2) hypertextuality; terstruktur sebagai sebuah sistem manifold hubungan on-linear antara teks, yang memungkinkan mahasiswa untuk mengikuti jalan mereka sendiri dan untuk membuat yang baru setiap kali; (3) interaktivitas; memungkinkan untuk bekerja dengan materi dalam pendekatan belajar melalui 
kerja dengan keterlibatan yang lebih tinggi, pemahaman yang dalam, dan retensi yang lebih baik dari subjek (Lee \& Owens, 2000).

Perrin dan Mayhew (2000) menyatakan pertimbangan lain adalah untuk mengatasi permasalahan yang diakibatkan keterbatasan tenaga pengajar yang berkualitas. Pembelajaran ini dapat menggunakan salah satu dari dua sistem pembelajaran, yaitu (1) real-time, pengajaran secara langsung yang membutuhkan dukungan aplikasi Java Chat, Java Whiteboard, Java Projector, dan Java Newsticker dan (2) knowledgebased, menggunakan sistem sebagai tempat pemusatan pengetahuan dengan aplikasi manajemen dokumen. Faktor inilah yang dipilih sebagai strategi dalam penelitian ini. Dalam perancangan perangkat lunak dapat memilih salah satu model yang ada, yaitu (1) Model Sekuensial Linear; (2) Model Prototipe; (3) Model RAD (Rapid Application Development); (4) Model RAD; (5) Model Incremental; (6) Model Metode Formal Engineer; (7) Model Generasi Keempat,memberikan kemudahan bagi software yang diinginkan (Pressman, 2000). Secara umum langkah-langkah yang ditempuh terdiri dari empat bagian utama, yaitu analisis, perancangan, pengkodean dan pengujian.

Bahan ajar berbasis website disusun dan dikembangkan dengan menggunakan alat bantu website untuk mengolah data, termasuk memroses, mendapatkan, menyusun, menyimpan, memanipulasi data dalam berbagai cara untuk menghasilkan informasi yang berkualitas.

Objek ajar merupakan salah satu layanan yang dimiliki oleh jaringan komputer global (internet) dapat berupa (1) teks, (2) gambar, (3) audio, (4) video, dan (5) animasi.

Media pengajaran merupakan salah satu unsur penting dalam belajar dan pembelajaran yang dapat mempertinggi kualitas proses belajar (Gralbreath, 1996). Smith \& Ragan (2005) menyatakan diperlukan perencanaan untuk menerjemahkan prinsip-prinsip pembelajaran dan instruksi ke dalam rencana bahan pembelajaran dan aktivitas pembelajaran. Pengembangan pem- belajaran berbasis website (PBW) dalam penelitian ini ditinjau dari dua tujuan umum, (1) efficiency, yaitu upaya untuk mengurangi obligasi ruang dan waktu proses pembelajaran, pembelajaran berbasis website beroperasi sebagai suplemen pendidikan atau pembelajaran tradisional;(2) effectiveness, yaitu upaya untuk meningkatkan proses pembelajaran (Keeton, 2004).

Sistem ini merupakan model sistem universal yang terdiri dari (1) input, (2) cara atau proses transformasi input menjadi output atau produk, (3) keluaran dari produk, dan (4) mekanisme umpan balik dari aktivitas Beck \& Schornack(2003). Model ini digunakan karena menganalisis sumber input, yaitu orang, pengetahuan, material, energi, modal, dan keuangan. Untuk tahap proses, diidentifikasi kebutuhan yang berupa sumber daya, mekanisme penyampaian, interaksi, navigasi, penataan layout. Untuk tahap, output dapat berupa bahan pembelajaran, sumber daya, dan pengalaman yang diperoleh peserta didik.

Pengembangan pembelajaran dalam hal ini adalah merupakan proses sistematik website dengan ciri-ciri (1) didasarkan pada teori belajar/pembelajaran dan riset bidang kognisi, psikologi pendidikan, dan pemecahan masalah; (2) mencakup proses analisis kebutuhan dan tujuan belajar, pengembangan sistem penyampaianmaupun lingkungan belajar, dan pengorganisasian sumber-sumber belajar; (3) berisi rencana materi, proses dan aktivitas pembelajaran; dan (4) dilakukan secara berulang yang memerlukan evaluasi dan umpan balik secara berkelanjutan.

\section{METODE}

Penelitian ini dilaksanakan dengan metode Research and Development (Borg dan Gall 1983) pada JPTE dengan melibatkan mahasiswa, guru SMK dan dosen untuk mengembangkan produk pembelajaran berbasis website pada jaringan internet untuk mata kuliah pengaturan mesin listrik. Tahapan penelitian adalah (1) analysis, (2) design, (3) development, (4) implementation dan (5) evaluation seperti Gambar 1. 


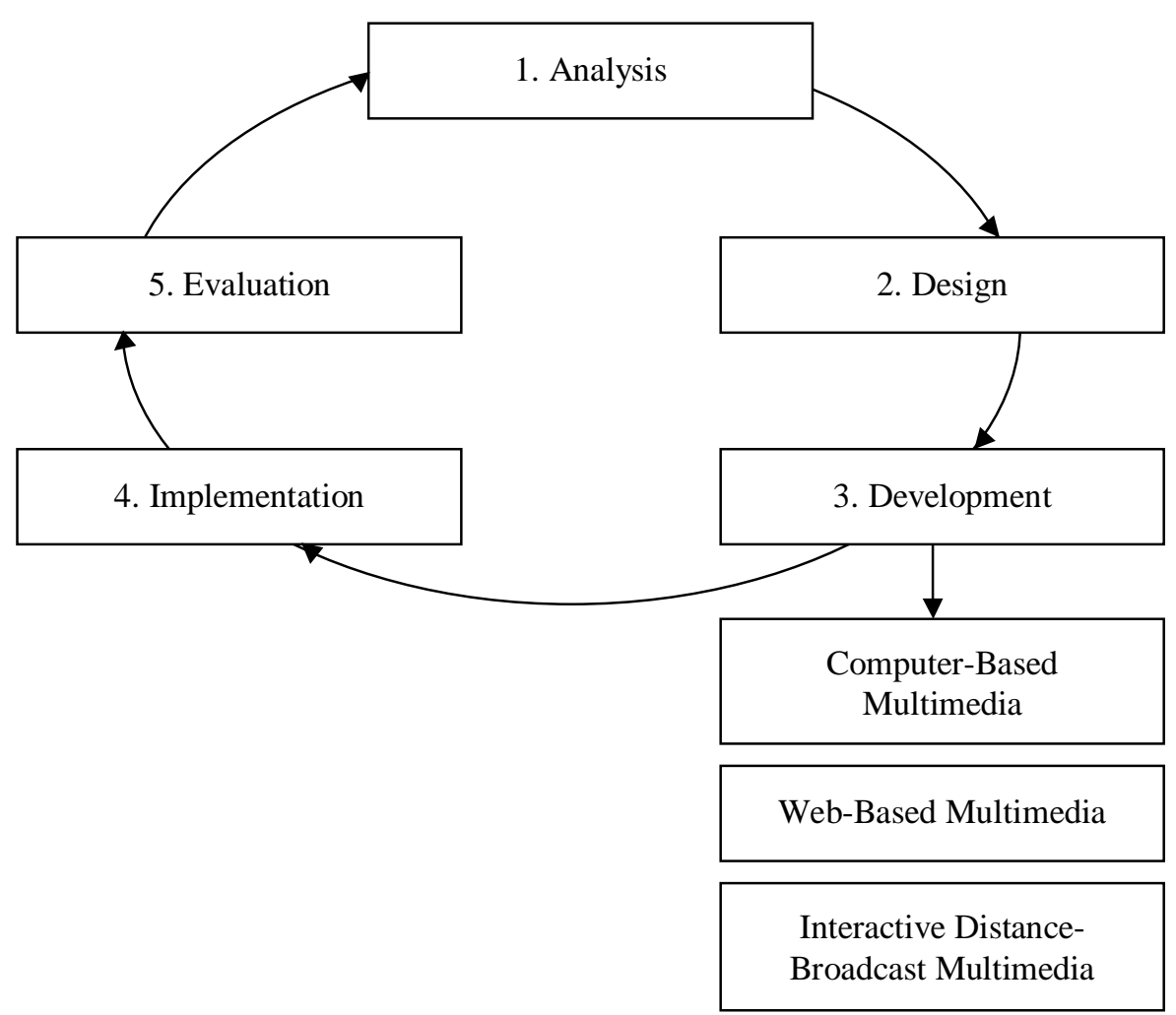

Gambar1. Desain Pembelajaran Berbasis Website

Yang menjadi dasar perancangan pembelajaran berbasis website pada tahap pertama ini dilakukan survei tentang penggunaan metode pembelajaran, konten, dan keterampilan. Data penelitian diperoleh melalui studi literatur, review ahli, observasi, interiew, penyebaran angket dan dokumentasi. Data tentang uji para ahli dianalisis dengan teknik analisis deskripfif.

\section{HASIL DAN PEMBAHASAN}

Surveiterhadap 20 orang mahasiswa, lima belas (15) orang lulusan yang sudah bekerja sebagai guru di SMK dan tiga orang dosen Jurusan Pendidikan Teknik Elektro (JPTE) Fakultas Teknik UNIMED menggunakan lembar observasi, berkaitan metode pembelajaran atau penyampaian materi, konten, dan keterampilan diperoleh hanya $14 \%$ dari responden lebih menyukai pendidikan sepenuhnya online, $25 \%$ mahasiswa memilih tatap muka secara langsung, $30 \%$ mahasiswa dengan aktivitas online yang lebih disukai dengan pertemuan kelas dan $31 \%$ dari responden lebih suka pertemuan tatap muka dengan pembelajaran online dan tugas. Tatap muka secara online dan tugas lebih di- sukai oleh semua dari tiga kelompok mahasiswa $(\mathrm{M}=3,30)$, professional (guru SMK) $(\mathrm{M}=$ $3,46)$, dan dosen JPTE $(M=4,00)$. Pembelajaran sepenuhnya online yang paling disukai oleh ketiga kelompok, yaitu mahasiswa $(\mathrm{M}=1,56)$, guru SMK $(\mathrm{M}=1,50)$ dan dosen JPTE $(\mathrm{M}=$ 1,00). Aktivitas online dengan pertemuan kelas adalah peringkat kedua dan pertemuan tatap muka eksklusif menduduki peringkat ketiga dengan semua tiga kelompok.

Analisis grafis dari respon dari tiga kelompok ditunjukkan dalam Gambar 3. Dalam hal isi, desain prinsip-prinsip Cetak, CBT atau berbasis Web layar desain, dinilai sangat tinggi dengan rata-rata total 3,82, mahasiswa $(\mathrm{M}=$ $3,85)$ dosen SMK $(\mathrm{M}=3,73)$ dosen JPTE $(\mathrm{M}=$ 4,00). Audio, video, dan bahan instruksional Multimedia yang dinilai tinggi oleh para dosen SMK $(M=3,80)$. Games dan simulasi menduduki peringkat terendah dengan rata-rata total 2,92 , mahasiswa $(\mathrm{M}=2,75)$ profesional $(\mathrm{M}=$ $3,13)$ dosen $(\mathrm{M}=3,00)$.

Pesan prinsip-prinsip desain juga disukai oleh semua tiga kelompok dan memiliki ratarata total 3,45 . Analisis dan desain dan produksi 
produk media pembelajaran dinilai tinggi oleh mahasiswa $(\mathrm{M}=3,50)$ dan profesional dianggap sebagai analisis masalah instruksional menjadi keterampilan yang paling penting ( $\mathrm{M}=$ 3,79). Keterampilan paling disukai oleh mahasiswa dan kategori profesional adalah perkembangan kemampuan mahasiswa $(\mathrm{M}=2,75)$, profesional $(\mathrm{M}=3,00)$ dan rata-rata total responden 2,89. Perasaan terhadap online dari materi penggunaan motorlistrik. Tatap muka dikelas dengan sistem online dan tugas menjadi alternatif pilihan dari mahasiswa seperti tampak pada Gambar 2.

Analisis teknologi dalam pembelajaran ditinjau dari penerapan teknologi seperti (1) komunikasi; (2) referesi materi belajar secara online; (3) pengujian danpenilaian; (4) pelacakan, pelaporan; (5) distribusi pengiriman secara terorganisasi; (6) penyampaian; (7) desain dan pengembangan keahlian.

Hasil survei terhadap 114 responden tentang kemampuan pemanfaatan teknologi dan komunikasi dalam pembelajaran pengaturan mesin listrik diperoleh 112 responden $(98,24 \%)$ yang memanfaatkan email dalam pembelajaran. Dalam memanfaatkan jaringan sosial dalam kelompok pembelajaran $61,40 \%$ dan menggunakan Chat rooms adalah 42,98\%. Hal ini mengindikasikan, bahwa mahasiswa dan dosen dalam pembelajaran mempunyai kemampuan dalam memanfaatkan media komunikasi dalam pembelajaran.

Dalam bidang referensi mahasiswa dan dosen dalam pembelajaran yang menggunakan websites $85,96 \%$, video $43,85 \%$, dan buku buku teks secara online $61,40 \%$, menggunakan grafik dan gambar sebesar $87,72 \%$, sedangkan menggunakan panduan secara manual adalah sebesar $43,85 \%$. Berdasarkan data ini responden mempunyai kemampuan dalam memanfaatkan website dan grafik dan gambar dalam belajar. Penggunaan video pembelajaran masih sangat rendah penggunaannya.

Sehubungan dengan evaluasi akan hasil belajar dalam bentuk online diperoleh hasil survei dari 76 orang mahasiswa dan hanya $17,54 \%$ mampu memanfaatkan penilaian secara online sedangkan pelacakan hasil belajar ber- basis database dalam bentuk online diperoleh 90,35\% menyatakan dapat memanfaatkan database online untuk menjajaki hasil belajar mahasiswa.

Penyampaian bahan ajar untuk materi penggunaan motor listrik terhadap mahasiswa JPTE UNIMED diperoleh melalui jaringan LAN 26,32\%, melaui CD-ROM sebesar $72,80 \%$ dan melalui Flasdisc $89,47 \%$, menggunakan video $78,59 \%$ dan menggunakan Audio sebesar 26,32, melalui proses downloading sebesar $88,59 \%$ seperti Tabel 1. Bahan ajar penggunaan motor listrik dapat dipelajari oleh mahasiswa dengan memanfaatkam audio dan video yang diakses melalui server online sebanyak $43,85 \%$ dan menggunakan multimedia komputer sebanyak $87,72 \%$ mahasiswa, sedangkan memanfaatkan video teleconferencing sebanyak $17,54 \%$.

Tabel 1: Penyampaian Materi Ajar dengan $\mathrm{N}=76$

\begin{tabular}{lll}
\hline NO. & Jenis & Persentase \\
\hline 1. & LAN & 26,32 \\
2. & CD ROOM & 72,80 \\
3. & Flasdisc & 89,47 \\
4. & Downloading & 88,59 \\
5. & Video & 78,59 \\
6. & Audio & 26,32 \\
\hline
\end{tabular}

Hail survei tentang desain dan pengembangan pembelajaran pengaturan mesin listrik, diperoleh sebanyak 77,19\% membuat atau memproduksi pembelajaran dalam bentuk format video, $87,72 \%$ produksi audio, $84,21 \%$ dalam bentuk grafik atau gambar, bantuan online sebagai acuan produksi pembelajaran sebanyak $50 \%$, menggunakan pembelajaran berbasis komputer (CBL) authoring 85,96\%, web authoring $58,77 \%$ seperti pada Tabel 2 dan dalam bentuk histogram adalah pada Gambar 3. Berdasarkan hasil survei terhadap kemampuan mahasiswa dan dosen dalam hal pengembangan pembelajaran di atas, maka dapat dilaksanakan dan dibuat suatu website dalam pembelajaran pengaturan mesin listrik. 
Tabel 2. Kemampuan dalam Desain dan Pengembangan Pembelajaran dengan $\mathrm{N}=114$

\begin{tabular}{lll}
\hline No. & Jenis & Persentase \\
\hline 1. & $\begin{array}{l}\text { produksi video } \\
\text { pembelajaran }\end{array}$ & 77,19 \\
2. & $\begin{array}{l}\text { produksi audio } \\
\text { pembelajaran }\end{array}$ & 87,72 \\
3. & $\begin{array}{l}\text { produksi grafik dan gambar } \\
\text { produksi pembelajaran } \\
\text { dengan bantuan online }\end{array}$ & 84,21 \\
& 50.00 \\
5. & $\begin{array}{l}\text { Computer based learning } \\
\text { (CBL) }\end{array}$ & 85,96 \\
6. & Web authoring & 58,08 \\
\hline
\end{tabular}

Ketersediaan perangkat keras sudah dapat digunakan oleh mahasiswa untuk mengakses internet dan $80 \%$ mahasiswa sudah memiliki komputer yang berupa note book dan laptop. Spesifikasi perangkat keras tersebut adalah sebagai berikut (1) processor $2 \mathrm{Ghz}$, (2) memory $256 \mathrm{MB}$, (3) harddisk $40 \mathrm{~GB}$, (d) VGA 64MB, (4) Lan Card Realtek RTL 8139, (5) monitor 15 inchi, (6) mouse (7) keyboard, (8) Handy Cam Sony. Analisis perangkat lunak yang dibutuhkan, adalah Microsoft Windows XP dan Windows Seven sebagai sistem operasi PHP, MySQL, Internet Exporer, Mozilla, Macromedia Dreamweaver, Macromedia Flash, Corel Draw, Adobe Photoshop, Adobe Flash, software video editing, Converter Video. Perangkat keras dan lunak ini dapat membangun website dan aplikasi untuk pembelajaran pengartuaan mesin listrik. Fasilitas WiFi/Hot Spot dengan Bandwith spoel Unimed di atas $3 \mathrm{~Gb}$ juga tersedia.

Tanggapan Terhadap Metode Penyampaian Materi Pembelajaran

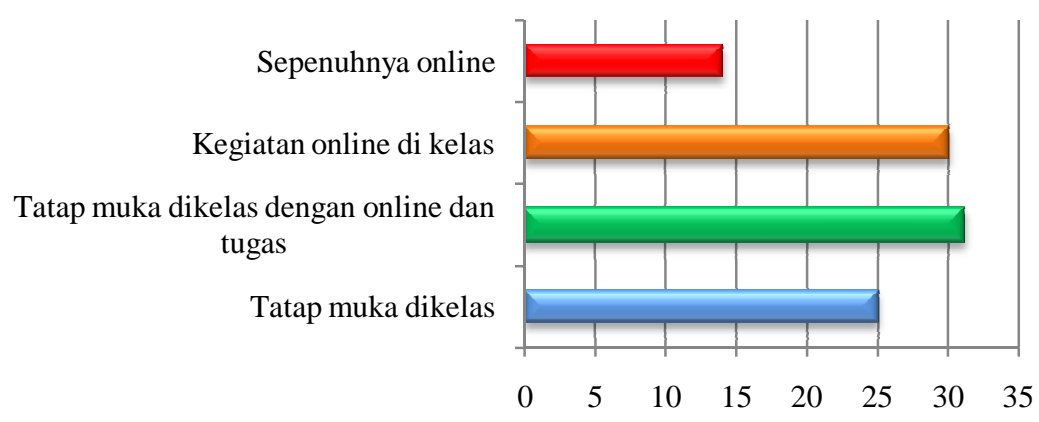

Gambar 2. Histogram Tanggapan terhadap Metode Pengiriman PBW

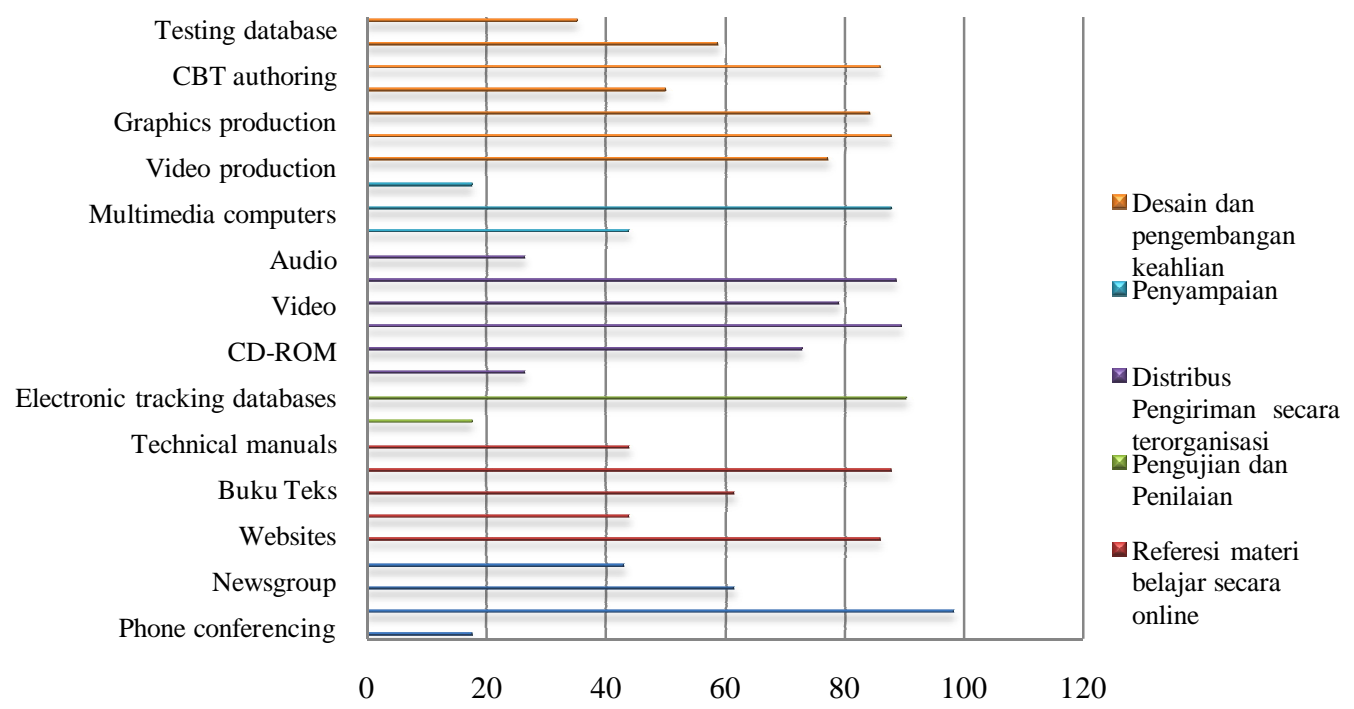

Gambar 3. Histogram Pemanfaatan Teknologi Pembelajaran 


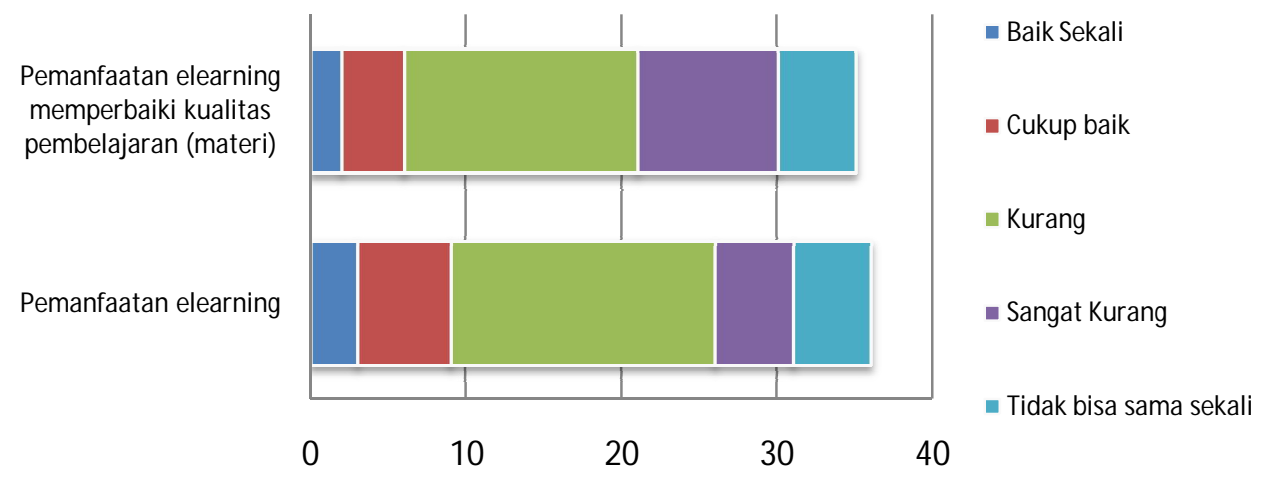

Gambar 4. Histogram Pemanfaatan e-Learning dan Peningkatan Kualitas Pembelajaran

Hasil survei tentang keberadaan media pembelajaran diperoleh keberadaan media yang digunakan dalam pembelajaran dengan rata rata sebesar 1,73, untuk kegunaan dari media tersebut 2,47 sedangkan keterkaitan media pembelajaran dengan materi ajar rata rata 2,42. Dengan demikian keberadaan media dalam pembelajaran dalam kategori kurang dan kegunaan dan keterkaitan media pembelajaran yang diharapkan oleh mahasiswa termasuk dalam kategori cukup. Dalam penggunaan dalam pembelajaran penggunaan motor listrik, bahwa media simulasi, alat dan bahan dalam bentuk actual dan virtual termasuk dalam kategori sangat kurang dengan rata rata 0,62 . Pembelajaran dengan menggunakan bantuan komputer CAI keberadaannya dalam kategori cukup, yaitu dengan rata rata 2,27 seperti gambar 5 .

Hasil survei tentang pemahaman dalam pemanfaatan e-learningterhadap 36 orang dosen diperoleh rata-rata 2,76. Dengan rentang skor satu sampai dengan lima. Terdapat $47,22 \%$ pada kategori kurang, 8,33\% pada tingkat baik sekali sedangkan tidak tahu sama sekali atau sangat kurang dalam pemanfaatan e-learning 27,6\%. Dalam bentuk histogram pada Gambar 4.

Analisis masalah di atas menunjukkan hal-hal sebagai berikut. (1) Mahasiswa tidak mampu merancang pengaturan mesin listrik dan sangat sulit mengenal komponen komponen elektrik dan elektronika yang digunakan. Program pembelajaran yang dilaksanakan selama ini sudah termasuk baik, namun mahasiswa tidak merasa senang dengan pembelajaran tersebut dan mahasiswa sangat sulit memahami mesinmesin listrik. Untuk ini, perlu model pembelajaran berbasis web dengan muatan yang dapat memotivasi mahasiswa untuk belajar tentang mesin-mesin listrik. Hal ini sejalan dengan penelitian Seddon dkk (2012) tentang penggunaan ICT dalam Scenario Based Learning (SBL) bahwa pembelajaran ini berpotensi menguatkan keterhubungan antara isi selama pembelajaran. (2) Sarana informasi yang masih kurang dalam hal mempromosikan atau memberikan layanan informasi kepada mahasiswa dan masyarakat luar sehingga dengan adanya situs e-learning ini dapat menambah media informasi dengan menyajikan informasi mengenai lembaga secara lengkap dan menarik dan materi pembelajaran. Sesuai dengan temuan penelitian tentang Web Quest learning systemdi Sekolah Menengah China oleh Hsiao dkk (2012) bahwa pembelajaran tersebut memberikan keuntungan bahwa pebelajar dapat mengatur diri sendiri untuk belajar. (3) Proses kegiatan belajar mengajar yang hanya dilakukan dalam beberapa pertemuan dalam seminggu, akibatnya ada matakuliah yang hanya mendapatkan porsi satu kali pertemuan dalam seminggu. Dapat dipastikan tidak banyak materi kuliah yang bisa disampaikan dan diserap oleh mahasiswa. (4) Mahasiswa merasa tidak termotivasi. (5) Seorang dosen terkadang berhalangan masuk karena ada kesibukan lain atau dalam keadaan sakit, dan tidak dapat mengajar pada jam yang bersangkutan sehingga 
dengan adanya sistem e-learning ini, dosen tersebut dapat mengganti proses mengajar tersebut dengan memberikan mereka tugas atau latihan dengan memasukkan soal-soal latihan yang dijawab mahasiswa dan materi-materi yang dipelajari.

Harapan para mahasiswa dapat membuat aplikasi mesin listrik dalam suatu pengendali, serta adanya sumber belajar dalam bentuk CD pembelajaran dan juga website pembelajaran. Dengan demikian, solusi yang ditawarkan adalah pembelajaran berbasis website secara online dan offline atau menggunakan $\mathrm{CD}$ pembelajaran untuk mempelajari perangkat dan pengendali mesin listrik melalui perangkat multimedia seperti animasi, video dan tutorial. Sejalan dengan penelitian yang dilakukan oleh Tiwari dan Singh (2011) tentang virtualisasi pengalaman praktek bahwa laboratory virtual yang merupakan pembelajaran berbasis web adalah efektif dalam pembelajaran.

Pada tahap analisis nonfungsional berikut analisis kebutuhan pengguna, analisis perangkat keras, analisis perangkat lunak dan analisis basis data yang digambarkan dengan ERD (Entity Relationship Digram). Spesifikasi pengguna aplikasi pembelajaran berbasis website (PBW) ini, dideskripsikan sebagai berikut. (1) Administrator, yaitu pengguna (user) yang melakukan pengolahan secara keseluruhan terhadap aplikasi sistem e-learning. Karakteristik yang dimiliki administrator adalah dapat mengetahui bagaimana fungsi dari perangkat lunak yang digunakan, sehingga admin dapat mengelola aplikasi e-learning ini dengan baik secara keseluruhan. (2) Dosen, yaitu staf pengajar yang memberikan pembelajaran kepada mahasiswa. Dalam hal ini dosen juga mendapatkan pembelajaran mengenai bagaimana aplikasi e-learning ini berjalan sehingga seorang dosen dapat menggunakan sistem e-learning ini dengan baik. (3) Mahasiswa, yaitu yang akan mendapatkan pembelajaran dan materi yang disampaikan oleh dosen. Dalam penerapannya, mahasiswa mendapatkan pembelajaran dalam pengoperasian sistem ini sehingga dapat mengakses situs e-learning ini dengan baik. Aliran data yang masuk ke sistem tampak seperti diagram konteks pada sistem aplikasi pembelajaran online tampak Gambar 5 .

Dalam desain PBW ini menjelaskan bahwa pengguna web dapat melakukan akses pada website dengan memilih menu yang ada seperti login ke dalam sistem sebagai admin, dosen maupun mahasiswa. Yang di dalamnya terdapat beberapa pilihan yang berbeda sesuai hak akses pada setiap pengguna. Di antaranya menambah dosen dan mahasiswa. Kemudian sistem akan mencari pilihan tersebut pada file pengolahan data kemudian menampilkan menu tersebut kepada pengguna. Proses di dalamnya yaitu proses input materi, proses pemilihan materi, proses download materi, proses pengolahan data latihan, proses pengolahan data forum, proses latihan, dan proses nilai latihan dan tes.

Pada DFD level 1 proses 1 ini menjelaskan detail dari proses 1, yaitu proses login, yang di dalamnya terdapat beberapa proses yaitu proses verifikasi id user, dan proses veryfikasi password. Proses verifikasi login merupakan proses pengecekan ke dalam basis data apakah data login dari pengguna sesuai dengan data yang ada dalam basis data. Sedangkan proses verifikasi Password adalah proses untuk mengetahui password yang dimasukkan sudah valid atau belum.

Perancangan basis data merupakan tahapan memetakan model konseptual ke model basis data yang dipakai. Perancangan basis data terbagi menjadi empat bagian yaitu diagram ER, skema relasi, perancangan tabel, kamus data. Entity Relationship Diagram (ERD) merupakan salah satu cara untuk mengolah database sehingga data tersebut dapat diketahui hubungan antara file dan teknik. Bentuk Entity Relationship Diagram (ERD) tampak seperti Gambar 6. Dari spesifikasi pada tahap analisis dapat menentukan data-data yang akan digunakan dan disimpan untuk mendukung sistem pembelajaran berbasis website ini dandapat menentukan relasi antardata. 


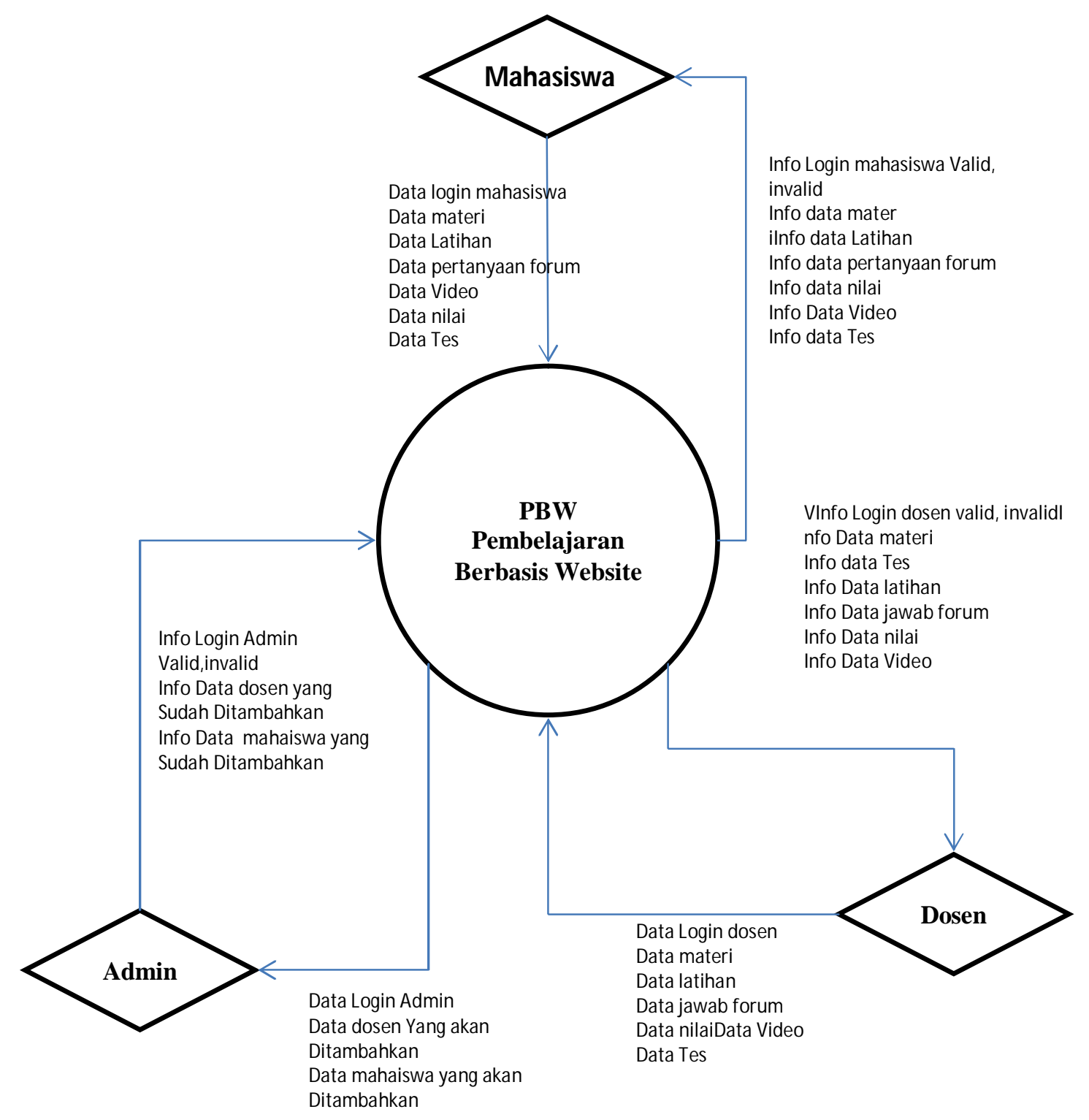

Gambar 5. Diagram Konteks PBW

Tabel-tabel dikelompokkan berdasarkan fungsi masing-masing, yaitu sebagai berikut. (1) Dosen dan mahasiswa, berisi detil informasi tentang dosen sebagai pengajar kuliah dan mahasiswa sebagai peserta kuliah. (2) Kuliah dan modul. Tabel-tabel ini membentuk rantai perkuliahan. (3) Topik dan file_materi, menentukan dimana lokasi materi-materi perkuliahan akan disimpan dan penamaan file, sehingga file dapat diakses oleh mahasiswa. File materi berupa file HTML,SWF, grafik dan foto, presentasi, audio, dan video, software engineering. (4) Konektor 1 dan konektor2,berfungsi sebagai penghubung bagi dua tabel yang saling memiliki relasi. Konektor1 menghubungkan tabel mahasiswa dengan kuliah, konektor2 menghubungkan antara dosen, dan kuliah. Berikut ini adalah gambar struktur tabel perkuliahan. Skema relasi merupakan rangkaian hubungan antara dua tabel atau lebih pada sistem database. Gambar 6 merupakan penjelasan rangkaian database pada aplikasi pembelajaran on-line. Implementasi halaman web terdiri dari halaman statis dan dinamis (HTML dan .PHP) seperti Gambar 7. 


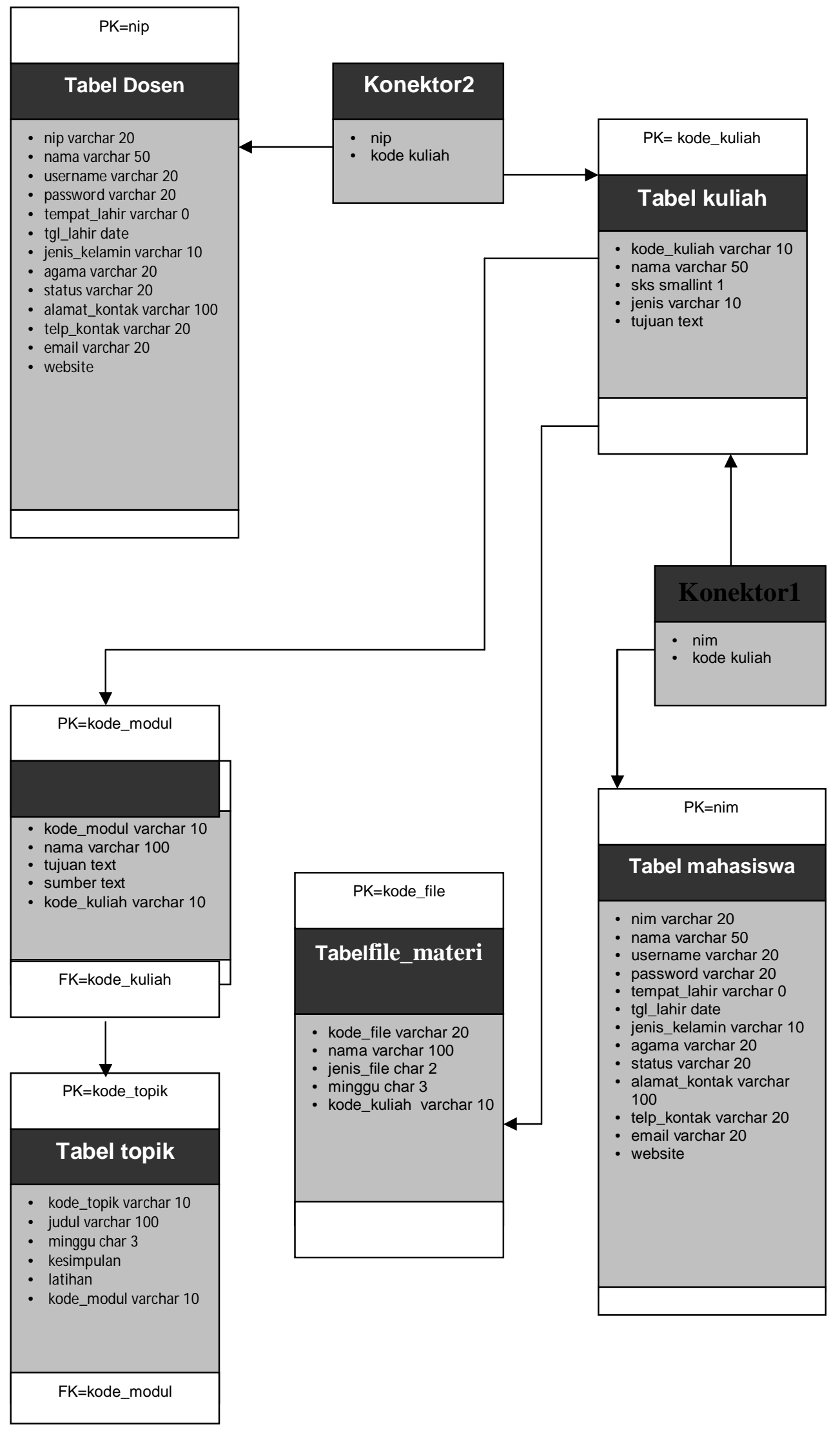

Gambar 6. Skema Tabel Relasi pada Sistem Pembelajaran On-Line 


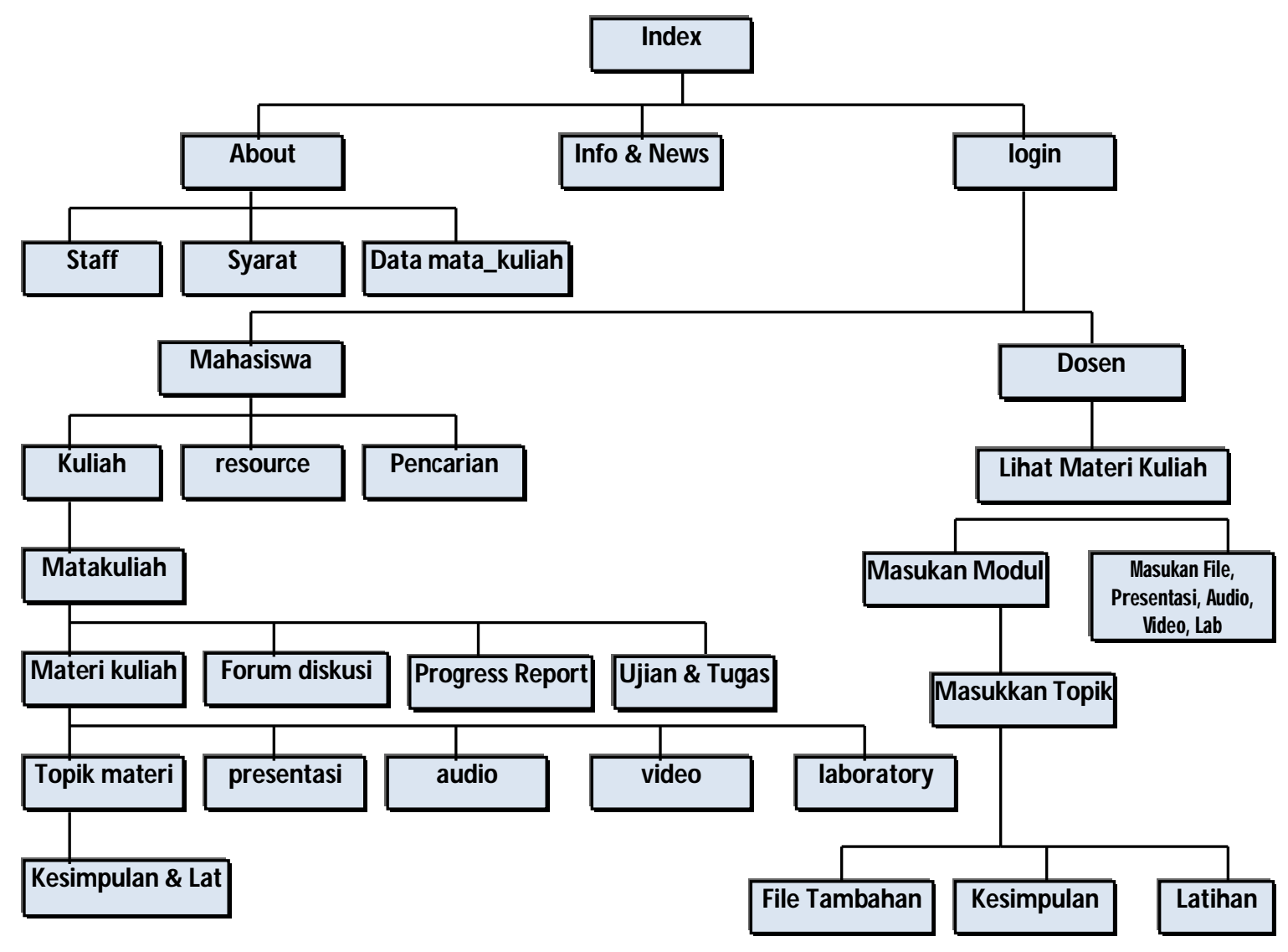

Gambar 7. Diagram Web Pembelajaran

(1) Index, merupakan halaman muka dari Sistem Pembelajaran Jarak Jauh. (2) About, merupakan halaman yang berisi informasi mengenai Distance Learning. (3) Info \& News, berupa halaman yang menampilkan berita dan informasi sekitar distance learning. (4) Staff, merupakan halaman yang menampilkan data dari dosen, staff, dan mahasiswa. (5) Syarat, berisi persyaratan untuk mengikuti perkuliahan berbasis WEB. (6) Data mata kuliah, merupakan halaman yang menampilkan daftar mata kuliah yang ada. (7) Login, merupakan file yang menangani proses authentifikasi user pada sistem. Bila username/password cocok dengan database mahasiswa, maka script akan memilih session mahasiswa, sedangkan bila cocok dengan database dosen, maka dialihkan ke session dosen. (8) Mahasiswa, merupakan sesi mahasiswa yang berisikan menu-menu untuk mahasiswa. (9) Kuliah, merupakan halaman perkuliahan dari mahasiswa. Pada file ini akan ditampilkan mata kuliah yang sedang diambil. (10) Resource, merupakan virtual library untuk perkuliahan jarak jauh. Ini digunakan untuk menampilkan data-data buku, artikel, dan alamat-alamat web yang dapat mendukung perkuliahan. (11) Pencarian, digunakan untuk mencari data-data modul atau topik perkuliahan yang ada. (12) Mata kuliah, berisikan detail materi kuliah tiap mata kuliah. Pada halaman ini akan ditampilkan daftar modul kuliah, topik materi, daftar file presentasi, audio, video, virtual laboratori, penugasan kelas, dan ujian. Pada setiap topik ditampilkan kesimpulan dan latihan. (13) Forum Diskusi, digunakan sebagai media interaksi untuk berdiskusi antara mahasiswa dengan dosen berkaitan dengan mata kuliah yang bersangkutan. (14) Progress Report, menampilkan aktivitas mahasiswa terhadap sistem perkuliahan jarak jauh. Data-data yang ditampilkan seperti : aktivitas berdiskusi, pengerjaan tugas, mid term, dan ujian akhir. Aktivitas akan di nilai dengan grade tertentu. (15) Ujian \& Tugas, merupakan halaman untuk melihat tugas yang diberikan dosen atau untuk mengikuti ujian yang diberikan. (16) Dosen, merupakan sesi dosen yang 
berisikan daftar mata kuliah yang diajar dan menu untuk memasukkan materi perkuliahan; (17) Lihat materi kuliah, digunakan untuk menampilkan daftar materi kuliah seperti modul kuliah, topik materi, dan file pendukung perkuliahan. (18) Masukkan modul, digunakan untuk memasukkan data modul perkuliahan ke dalam database. (19) Masukkan file presentasi, audio, video, dan virtual lab, digunakan untuk memasukkan file-file pendukung perkuliahan. File ini ditampilkan berdasarkan minggu. (20) Masukkan topik, merupakan halaman untuk memasukan topik materi (upload file) perkuliahan yang berupa file html, ke direktori di server. Setelah memasukkan data topik ke database, maka dapat dimasukkan kesimpulan, latihan, dan file pendukung topik materi. File ini akan diakses mahasiswa sebagai isi dari materi kuliah yang diberikan dosen.

\section{PENUTUP}

Berdasarkan hasil analisis yang dilakukan dapat disimpulkan bahwa pembelajaran berbasis website dalam pengaturan mesin listrik dapat memenuhi kebutuhan dasar dalam menunjang kegiatan pembelajaran, yaitu (1) memenuhi pengelolaan data materi pembelajaran; (2) memenuhi proses pembelajaran secara kontruktivis; (3) disajikan dengan materi pembelajaran yang interaktif; (4) dapat diunduh oleh mahasiswa, dan menampilkan materi dalam bentuk link; (5) memenuhi proses pembelajaran secara inkuiri, yang disajikan dengan fasilitas pencarian (search) materi, sarana forum diskusi, dan kontribusi aktif (komentar); (6) memenuhi proses evaluasi sehingga dapat diketahui tingkat penguasaan mahasiswa tentangmateri pembelajaran; (7) materi dibuat dalam bentuk animasi dengan menggunakan macromedia flash, video, dan teks.

Bentuk desain sistem, yaitu (1) desain proses dengan diagram alir dan diagram arus data; (2) desain basis data dengan Entity Relationship Diagram; dan (3) desain antarmuka dengan menggunakan gui desain.

Analisis kebutuhan menunjukkan proses pembelajaran berbasis web dalam matakuliah pengaturan mesin listrik memenuhi kebutuhan
(1) pengelolaan data tema, topik, dan sub topic; (2) menyajikan materi pembelajaran dalam bentuk tulisan, presentasi, dan link; (3) menampilkan media pembelajaran interaktif; (4) pencarian materi (search); (5) menyediakan sarana diskusi antara dosen dengan mahasiswa dan antarmahasiswa; (6) menyediakan sarana bagi pengguna untuk memberikan kontribusi aktif; (7) pengelolaan data latihan soal dan evaluasi.

Analisis hasil desain pembelajaran berbasis web dalam matakuliah pengaturan mesin listrik menunjukkan (1) komponen-komponen yang membangun model-model diagram arus data dalam desain perancangan pembelajaran berbasis web sesuai dengan spesifikasi dan kebutuhan dasar dalam pembelajaran; (2) desain antarmuka yang dibuat sesuai dengan proses yang digambarkan dalam diagram arus data dan sesuai dengan kebutuhan dalam pembelajaran berbasis web pengaturan mesin listrik; (3) proses validasi atas potongan program dibuat untuk mengetahui pembuatan program sesuai dengan kebutuhan.

Dengan selesainya penelitian pengembangan pembelajaran berbasis website dalam matakuliah pengaturan mesin listrik ini yang melibatkan berbagai pihak, baik mahasiswa maupun dosen jurusan pendidikan teknik elektro sepatutnya disampaikan terimakasih dengan harapan agar dapat secara bersamasama mengembangkan pembelajaran dalam bentuk lain.

\section{UCAPAN TERIMAKASIH}

Pada kesempatan ini perkenankan saya mengucapkan terima kasih kepada lima belas (15) orang lulusan yang sudah bekerja sebagai guru di SMK dan tiga orang dosen Jurusan Pendidikan Teknik Elektro (JPTE) Fakultas Teknik UNIMED, Ketua Penyunting Jurnal CP LPPMP dan Sekretaris LPPMP yang telah bersedia mereviu tulisan ini menjadi lebih baik dari sisi substansi dan cara pemaparannya. Semoga Tuhan Yang Maha Kuasa memberkati semua pihak yang telah membantu saya dalam penulisan ini dan dimuat dalam Jurnal CP LPPMP. 


\section{DAFTAR PUSTAKA}

Beck, CE \& Schornack, GR. 2003. Theory and Practice for Distance Education: A Heuristic Model for the Virtual Classroom. USA: Idea Group Publishing.

Borg, Walter R.\& Gall, Meredith D. 1983. Educational research: an introduction. $4^{\text {th }}$ Edition. USA: Longman.

Conrad, Kerri \& Voris, Alvin C. 2002. Instructional Design for Web-Based Training. USA: HRD Press.

Gilbert, \& Jones, M. G. 2001. E-learning is eNormous. Electric Perspectives.Vol.26, No. 3, 2001, pp. 66-82.

Gralbreath, Sally \& Brenda Smith.1996. Esource-Based Learning. London: Kogan Age Limited.

Hsiao, Hsien-Sheng et.al. 2012. "Implementing a Self-Regulated WebQuest Learning System for Chinese Elementary Schools." Australasian Journal of Educational Technology, 2012, Vo.28, No.2, pp.315340. http://www.ascilite.org.au/ajet/ajet28/hsiao-hs.html.

Keeton, M. T. 2004. "Best Online Instructional Practices: Report of Phase I of an Ongoing Study," Journal of Asynchronous Learning Networks, Vol. 8, No. 2, 2004, pp. $75-100$.

Lee, William W \& Owens, Diana L. 2000. Multimedia-based Instructional Design: Computer-Based Training; Web-Based Training; Distance Broadcast Training; Performance-Based Solutions, Second
Edition. San Fransisco: Jossey Bass/ PFIEFFER A Willey Company.

Perrin, Kay M. \& Mayhew, Dionne. 2000. The Reality of Designing and Implementing an Internet-based Course. Florida: University of South Florida, College of Public Health.

Pressman, Roger S. 2000. Interactive E-source to Accompany Software Engineering. USA: McGraw-Hill.

Rosenberg, M. J. 2001. E-learning: Strategies for Delivering Knowledge in the Digitalage. New York: McGraw-Hill.

Seddon, Jennifer M. 2012. "ICT-Supported, Scenario-Based Learning in Preclinical Veterinary Science Education: Quantifying Learning Outcomes and Facilitating the Novice-Expert Transition." Australasian Journal of Educational Technology. 2012, Vol.28, No.2, 214-231. http://www.ascilite.org.au/ajet/ajet28/seddon.ht $\mathrm{ml}$.

Smith, Patricia L. and Ragan, Tillman J. 2005. Instructional Design. Third Edition. USA: John Wiley \& Sons, Inc.

Stone, Biz. 2002. Blogging: Genius Strategies For Instant Web Content. USA: New Riders Publishing.

Tiwari, Rajiv and Singh, Khilawan. 2011. "Virtualisation of Engineering Discipline Experiments for an Internet-Based Remote Laboratory." Australasian Journal of Educational Technology, Vol.27, No. 4, 2011, pp. 671-692. http://www.ascilite.org.au/ajet/ajet27/tiwari.html 